\title{
Expression of NGF and NT3 mRNAs in Hippocampal Interneurons Innervated by the GABAergic Septohippocampal Pathway
}

\author{
Nativitat Rocamora, ${ }^{1}$ Marta Pascual, ${ }^{1}$ Laszlo Acsàdy, ${ }^{2}$ Luís de Lecea, ${ }^{3}$ Tamàs F. Freund, ${ }^{2}$ \\ and Eduardo Soriano ${ }^{1}$ \begin{abstract}
2Institute of Experimental Medicine, Hungarian Academy of Sciences, $\mathrm{H}-1450$ Budapest, Hungary, and ${ }^{3}$ Department of Molecular Biology, The Scripps Research Institute, La Jolla, California 92037
\end{abstract} \\ ${ }^{1}$ Department of Animal and Plant Cell Biology, Faculty of Biology, University of Barcelona, Barcelona 08028, Spain,
}

We used in situ hybridization for the detection of nerve growth factor (NGF), brain-derived neurotrophic factor (BDNF), and neurotrophin 3 (NT3) mRNAs combined with immunocytochemistry against the calcium-binding proteins parvalbumin (PARV), calbindin 28K (CALB), and calretinin (CALR) to determine the expression of neurotrophins in functionally distinct subsets of hippocampal interneurons. Most PARVimmunoreactive neurons in the hippocampus were NGF mRNA-positive (82\%), which corresponds to $71 \%$ of NGFpositive neurons in the hippocampus proper and in the dentate gyrus (excluding granule cells). In contrast, only a subset of CALB- and CALR-immunoreactive interneurons $(24 \%$ and $23 \%$, respectively) displayed hybridization signals for NGF. Small subsets of PARV- and CALR-positive cells expressed NT3 mRNA, but we did not find hippocampal interneurons expressing BDNF mRNA. These results show that NGF and NT3 genes are differentially regulated in distinct subsets of GABAergic cells, and these interneurons are a major source of NGF production in the hippocampus.

We also addressed whether hippocampal interneurons expressing neurotrophins were targets of the GABAergic septo- hippocampal pathway. We developed a triple-labeling method that combines anterograde tracing of this pathway by means of Phaseolus vulgaris leucoagglutinin injections, with in situ hybridization for the detection of neurotrophins, and immunocytochemistry for calcium-binding proteins. Virtually every PARVpositive neuron innervated by GABAergic septohippocampal baskets expressed NGF mRNA (86\%), whereas $39-59 \%$ of CALR- and CALB-positive interneurons that were contacted by GABAergic septohippocampal axons showed NGF gene expression. A small subset of NT3 mRNA-expressing interneurons was also innervated by septohippocampal baskets. These findings show that the GABAergic septohippocampal pathway preferentially terminates on interneurons expressing NGF mRNA, suggesting that this neurotrophic factor might be involved in the specification of this connection and in its maintenance and normal function in the adult brain.

Key words: rat hippocampus; GABAergic interneurons; neurotrophic factor expression; nerve growth factor; neurotrophin 3; calcium binding proteins; septohippocampal connections; cholinergic afferents
Neurotrophins, including nerve growth factor (NGF), brainderived neurotrophic factor (BDNF), and neurotrophins 3 and 4/5 (NT3, NT4), are believed to play a critical role in the development and maintenance of synaptic connections and to support the survival of afferent neurons. For this to occur, the production of neurotrophic factors by target cells and the expression of specific receptors by afferent fibers must be coordinated temporally and spatially, in both adult and developing nervous tissue (Barde, 1989; Korsching, 1993; Davies, 1994). For the peripheral nervous system, there is evidence that several of these neurotrophins may have specific actions on distinct subpopulations of developing and mature sensory and sympathetic neurons. In addition, BDNF and NT3, and more recently NT4, may be the specific neurotrophins

Received Dec. 19, 1995; revised March 18, 1996; accepted March 21, 1996.

This research was supported by Grants FIS93-0369, SAF94-743, and CIRIT/ GRQ93-1099 (Spain) to E.S. and by the National Scientific Research Foundation (Hungary), the Human Fronticr Science Program, and the Howard Hughes Medical Institute to T.F.F. N.R. was a recipient of a Ministerio de Educacion y Ciencia (Spain) postdoctoral fellowship. We are indebted to E. Arenas for the gift of the NGF cDNA probe. We thank Drs. P. Gaspar, R. Miles, R. Rycroft, and C. Sotelo for critical reading of this manuscript.

Correspondence should be addressed to Dr. Eduardo Soriano, Departamento de Biología Celular Animal y Vegetal, Facultad de Biología, Universidad de Barcelona, Diagonal 645, Barcelona 08028, Spain.

Copyright $\odot 1996$ Society for Neuroscience $0270-6474 / 96 / 163991-14 \$ 05.00 / 0$ that regulate the survival of motor neurons and the formation of neuromuscular synapses at sequential developmental stages (Davies, 1994; Ernfors et al., 1994; Johnson and Oppenheim, 1994; Jones et al., 1994; Klein et al., 1994; Snider, 1994; Funakoshi et al., 1995; Mettling et al., 1995).

In the CNS, NGF is believed to be essential for the development, normal function, and survival of septohippocampal cholinergic neurons (Hefti, 1986; Hartikka and Hefti, 1988; Burke et al., 1994; Svendsen et al., 1994). There is recent evidence, however, that adult cholinergic septohippocampal neurons survive after axotomy and/or target ablation and that they are not dramatically affected in transgenic mice lacking the NGF or Trk genes (Sofronicw et al., 1990, 1993; Naumann et al., 1992; Crowley et al., 1994; Smeyne et al., 1994). These data indicate that NGF may be required not for the survival of these neurons but rather for other functional aspects, such as the expression of their cholinergic phenotype or the formation of the pattern of efferent connections. Moreover, the role of NGF in specifying the connectivity of cholinergic circuits in the hippocampus is not clear because (1) cholinergic afferents to the hippocampus are distributed in a rather diffuse form, with no apparent preference for particular neuronal types (Frotscher and Leranth, 1985; Leranth and Frotscher, 1987), and (2) a large number of targets of the cholin- 
ergic afferents (namely the pyramidal neurons) do not show detectable levels of NGF mRNA (Lauterborn et al., 1993). NGF, however, might act coordinately with BDNF on cholinergic septohippocampal neurons, because BDNF is expressed widely in the hippocampus and seems to participate in the trophic support of septal cholinergic neurons (Alderson et al., 1990; Knüsel et al., 1991; Wetmore et al., 1991; DiStefano et al., 1992; Burke et al., 1994).

The septohippocampal pathway has a second set of fibers, the GABAergic component (Köhler et al., 1984), whose dependence on trophic factors is not understood. GABAergic septohippocampal fibers, like cholinergic axons, arise from the medial septum/ diagonal band complex and establish synaptic contacts almost exclusively with hippocampal GABAergic interneurons (Freund and Antal, 1988; Gulyás et al., 1990; Acsàdy et al., 1993). The axons from this component form multiple pericellular arrays of houtons around the cell bodies and dendrites of various interneuronal cell types. Because GABAergic hippocampal interneurons are known to control the activity of large numbers of hippocampal principal neurons (Soriano et al., 1990; Gulyás et al., 1993a,b; Han et al., 1993; Buhl et al., 1994), activation of the GABAergic septohippocampal pathway is proposed to lead to a powerful disinhibition or synchronization of hippocampal principal cells (Tóth et al., 1995). Moreover, the high degree of target specificity achieved by GABAergic septohippocampal axons, which ignore the far more numerous principal neurons and select GABAergic interneurons as postsynaptic targets, would require rather exquisite mechanisms of synaptic specification, which have not been elucidated. These considerations, together with the recent finding that NGF mRNA is expressed in GABAergic hippocampal neurons (Lauterborn et al., 1993), raise the possibility that neurotrophic factors may participate in the formation of the GABAergic septohippocampal pathway and its maintenance in the adult.

In the present study, we used in situ hybridization for the detection of neurotrophins, combined with immunocytochemistry against several interneuronal markers, and we show that NGF and NT3 gene expression is differentially regulated in distinct subsets of hippocampal interneurons, whereas BDNF mRNA is absent in these neurons. In a second set of experiments, we combined anterograde axonal tracing with Phaseolus vulgaris leucoagglutinin (PHAL) and in situ hybridization histochemistry, and we show that hippocampal interneurons expressing NGF and NT3 are targets of GABAergic septohippocampal axons, thus supporting a role of these trophic factors in the specification and normal functioning of the GABAergic septohippocampal pathway.

\section{MATERIALS AND METHODS}

In situ hybridization combined with immunocytochemistry. Wistar adult rats $(n=17)$ from our breeding colony were anesthetized decply with ether and perfused with $4 \%$ paraformaldehyde in $0.1 \mathrm{M}$ phosphate buffer, $\mathrm{pH}, 7.4$. After they were dissected, brains were postfixed in the same solution overnight, cryoprotected in $30 \%$ sucrose, and fromen on dry ice. Coronal sections $(25 \mu \mathrm{m})$ were kept in a cryoprotectant solution at $-70^{\circ} \mathrm{C}$ until use.

In situ hybridization histochemistry and immunocytochemistry were performed sequentially on "free-floating" tissue sections, essentially as described elsewhere (Gall and Isackson, 1989; de Lecea et al., 1994). Sections were deproteinized with $0.2 \mathrm{~N} \mathrm{HCl}$, acetylated with $0.25 \%$ acetic anhydride in $0.1 \mathrm{M}$ tricthanolamine, $\mathrm{pH} 8.0$, and prehybridized for $3 \mathrm{hr}$ at $55^{\circ} \mathrm{C}$ in a solution containing $50 \%$ formamide, $0.62 \mathrm{M} \mathrm{NaCl}, 10 \%$ dextran sulfate, $50 \mathrm{~mm}$ DTT, $20 \mathrm{~mm}$ PIPES, pH 6.8, 0.2\% SDS, $10 \mathrm{~mm}$ EDTA, $5 \times$ Denhardt's solution, and $500 \mu \mathrm{g} / \mathrm{ml}$ sheared salmon sperm DNA. Prehybridization solution was drained off, and the antisense NGF, BDNF, or NT3 $\left({ }^{35} \mathrm{~S}\right)$-labeled riboprobes $\left(10-20 \times 10^{6} \mathrm{cpm} / \mathrm{ml}\right)$ were diluted in the same solution, to which $250 \mu \mathrm{g} / \mathrm{ml}$ yeast tRNA was added. Hybridization was performed at $55^{\circ} \mathrm{C}$ overnight. After they were rinsed, sections were incubated with $10 \mu \mathrm{g} / \mathrm{ml}$ RNase A in $10 \mathrm{~mm}$ Tris, pH 7.5, $5 \mathrm{~mm}$ EDTA, and $0.5 \mathrm{M} \mathrm{NaCl}\left(1 \mathrm{hr}\right.$ at $\left.37^{\circ} \mathrm{C}\right)$, and final stringency washes were carried out in $0.5 \times \mathrm{SSC} / 50 \%$ formamide $\left(3 \mathrm{hr}, 55^{\circ} \mathrm{C}\right.$ ) and in $0.1 \times \mathrm{SSC} / 0.5 \%$ sarkosyl $\left(1 \mathrm{hr}, 60^{\circ} \mathrm{C}\right)$.

Sections were rinsed in PBS and subsequently immunostained for calcium-binding protcins. Aftcr blocking with $10 \%$ normal goat scrum and $4 \%$ bovine serum albumin (BSA), sections were incubated overnight with rabbit polyclonal antibodies against parvalbumin (PARV), calbindin 28k (CALB), or calretinin (CALR) (diluted 1:2000; Swant antibodies, Bellinzona, Switzerland). These antibodies have been characterized elsewhere (Schwaller et al., 1993). Primary antibodies were visualized using biotinylated goat anti-rabbit antibodies and the avidin-biotin peroxidase complex (ABC) (both diluted 1:200; Vector Labs, Burlingame, CA). Immunoreagents were diluted in PBS containing $0.2 \%$ Triton X-100 and $0.5 \%$ BSA. Peroxidase was developed with $0.05 \%$ diaminobenzidine (DAB) and $0.005 \%$ hydrogen peroxide. Sections were mounted onto gelatinized slides, dipped in NTB-2 (Kodak) autoradiographic emulsion diluted $1: 1$, and exposed for $4-6$ weeks at $4^{\circ} \mathrm{C}$. Thereafter, sections were developed with Kodak D-19, fixed, and coverslipped with DPX.

Anterograde tracing with $P H A L$ combined with in situ hybridization and immunocytochemistry. Eight male Wistar rats $(200-300 \mathrm{gm}$ body weight; Charles River, Budapest, Hungary) were used for the PHAL-tracing experiments. The animals received bilateral or midline injections of PHAL (2.5\%, Vector) into the medial septum at two anteroposterior (AP) levels and at three dorsoventral (DV) injection points under Equitesin (chlornembutal $0.3 \mathrm{ml} / \mathrm{kg}$ ) anesthesia by iontophoresis $(5 \mu \mathrm{A}$ positive direct current, $7 \mathrm{sec}$ on/off cycle; Gerfen and Sawchenko, 1984). Stereotaxic coordinates for the midline injections were (from bregma): $\mathrm{AP}+0.4$ and +1.0 , and DV $7.8,6.8$, and 5.8 for both tracks. In the bilaterally injected animals, the same coordinates were used twice, taking the left and right sides of the medial sinus as lateral coordinates. This protocol results in PHAL injection in the medial septum and the vertical limb of the diagonal band, areas that have been reported to contain the highest proportion of PARV-containing GABAergic septohippocampal neurons (Freund, 1989; Kiss et al., 1990; Naumann et al., 1994).

After 1 week of survival, the animals were anesthetized again with Equitesin and perfused through the heart with $4 \%$ paraformaldehyde in $0.1 \mathrm{M}$ phosphate buffer. After they were dissected, the brains were postfixed overnight, cryoprotected with sucrose, frozen, and sectioned at $25 \mu \mathrm{m}$. Sections were then processed for in situ hybridization histochemistry for the detection of NGF, NT3, and BDNF transcripts, as described above. After they were blocked, the scctions wcrc incubated with a mixture of primary antibodies: biotinylated goat anti-PHAL (dilution 1:200; Vector) plus one of the rabbit-raised antibodies against PARV, CALB, or CALR (diluted 1:2000). The next day, anti-PHAL primary antibody was visualized by incubating the sections with $\mathrm{ABC}(2 \mathrm{hr})$ followed by development using DAB/cobalt as chromogen, which renders the reaction end-product black. Calcium-binding protein immunoreactivity was then visualized by sequential incubation with biotin-coupled goat anti-rabbit antibodies and the $\mathrm{ABC}$ ( $2 \mathrm{hr}$ each). This second immunoperoxidase reaction was developed with $\mathrm{DAB}$ alone. Thereafter, the sections were mounted, processed for emulsion autoradiography, and coverslipped as described above.

Analysis of the material. Microscopic observations, both qualitative and quantitative, were focused on sections corresponding to the dorsal third of the hippocampus. Because the autoradiographic background level was less than five to six silver grains per cell, neuronal somata were considered to show positive hybridization when they were overlaid by 12 or more autoradiographic silver grains, although positive neurons normally displayed $>25$ silver grains (see Figs. 2, 5). The distribution of double- and triple-labeled neurons in representative hippocampal sections was plotted onto camera lucida drawings. For the quantitative analysis, the numbers of immunoreactive neurons displaying positive and negative hybridization in different hippocampal fields were counted in 12-18 sections from two to three animals, for each calcium-binding protein.

Riboprobes and controls. BDNF and NT3 cDNA clones were obtained by PCR amplification of rat genomic DNA using 5'-AACATGTTCATGAGGGTCCG-3' and 5'-CTATCTTCCCCTCTTAATGGT-3' (BDNF) and 5'-GGTCAGAATTCCAGCCGATGA-3' and 5'-GGCACACACACAGGAAGTGTC-3' (NT3) oligonucleotides as primers, and the conditions described elsewhere (Isackson et al., 1991). Amplified sequences, corresponding to nucleotides 439-822 (BDNF) and 325-838 (NT3) of rat cDNA sequences (Hofer et al., 1990; Maisonpierre et al., 1990), were subcloned into PCRTMII. To obtain antisense riboprobes, plasmids were 
linearized with Xbal, and transcription was carried out in the presence of ${ }^{35}$ S-UTP using SP6, following the Promega Riboprobe Kit protocol. NGF cDNA clone, 777 bp of the rat prepro-NGF (Whittemore et al., 1988) subcloned into pXM, was a gift of E. Arenas (Karolinska Institute, Stockholm, Sweden). NGF fragment (nucleotides 1-777) was subcloned into pT7T3 (EcoRi), linearized by $S m a I$, and transcribed with T7. Control hybridizations, performed either with tissue pretreated with RNase $\Lambda$ or with sense strand-labeled riboprobes, did not show autoradiographic labeling above background levels.

\section{RESULTS}

\section{NGF and NT3 are expressed in different subsets of hippocampal interneurons}

To determine the types of interneurons expressing NGF, NT3, and BDNF in the rat hippocampus, radioactive in situ hybridization was combined with the immunoperoxidase detection of the calcium-binding proteins PARV, CALB, and CALR, which label nonoverlapping subpopulations of GABAergic hippocampal neurons (Celio, 1990; Gulyás et al., 1991; Miettinen et al., 1992). In agreement with previous studies (Gall and Isackson, 1989; Ernfors et al., 1990), NGF mRNA-positive neurons were distributed sparsely throughout the hippocampus proper (CA1-CA3), hilus, and dentate gyrus, tending to concentrate around the main neuronal laminae and the pyramidal and granule cell layers. In addition, the dentate granule cells showed weak autoradiographic signals (Fig. 1A). The distribution of PARV-immunoreactive neurons was also consistent with the literature (Kosaka et al., 1987; Katsumaru et al., 1988; Celio, 1990; Nitsch et al., 1990; Gulyás et al., 1991), with immunolabeled interneurons scattered around the pyramidal and granule cell layers and in the hilus (Figs. $1 B, 4$ ). A pericellular plexus of PARV-positive boutons around the unstained somata of granule and pyramidal neurons could also be seen (Figs. $1 B, 2 A$ ), corresponding to the axons of basket and axo-axonic chandelier cells (Katsumaru et al., 1988; Soriano et al., 1990; Gulyás et al., 1993a; Han et al., 1993; Buhl et al., 1994). Double-labeled preparations showed that most PARVimmunoreactive neurons were NGF mRNA-positive (Fig. $2 A, B$ ). As illustrated in Table 1,80-94\% of PARV-immunoreactive cells displayed NGF mRNA expression in the various hippocampal subdivisions. The degree of colocalization might be higher, in fact, because most PARV-positive, NGF mRNA-negative neurons were at the bottom of the tissue sections, which might have caused partial autoradiographic exposure. Furthermore, with the exception of the granule cells, up to $71 \%$ of the NGF mRNA-expressing neurons were PARV-positive in the hippocampus proper and dentate gyrus ( $n=933$ cells), further stressing the high degree of correspondence between PARV-immunostaining and NGF mRNA hybridization (Figs. 3, 4). In the hilar region, however, $67 \%$ of NGF mRNA-positive neurons $(n=244)$ were unlabeled using PARV antibodies.

The patterns of CALR- and CALB-immunostaining were markedly different from that described for PARVimmunoreactivity (Celio, 1990; Gulyás et al., 1991, 1992; Miettinen et al., 1992; Tóth and Freund, 1992). Thus, both CALR- and CALB-positive interneurons were present mainly in the plexiform layers outside the hippocampal cell layers (Figs. $1 D, F, 4)$. In addition, the dentate granule cells and their axons, the mossy fibers, and also a subpopulation of pyramidal neurons in the upper half of the pyramidal layer in CA1 displayed CALBimmunoreactivity (Fig. 1D). In sections hybridized for $\mathrm{NGF}$ mRNA and immunoreacted for CALB or CALR, double-labeled neurons were observed with both calcium-binding proteins (Figs. $2 C-F, 4)$. The percentages of CALB- and CALR-immunoreactive interneurons expressing NGF mRNA were low in the CA1 and dentate regions (5-17\%, Table 1$)$, the degree of colocalization being higher for both calcium-binding proteins in the CA3 and hilar regions ( $\sim 30 \%$, Table 1$)$. Double-labeled NGF/CALB- and NGF/CALR-positive neurons were present within all hippocampal layers intermingled with inmunureactive neurons, which did not display hybridization signals (Fig. 4). Most NGF/CALBpositive neurons, however, were located in the stratum oriens, whereas NGF/CALR-immunoreactive neurons tended to be abundant, particularly in the hilus and in the stratum lucidum and radiatum in CA3. In contrast, for both calcium-binding proteins, immunoreactive cells in the stratum radiatum and lacunosum moleculare of CAl were hardly seen to display NGF hybridization. With the exception of granule cells, CALB- and CALRimmunoreactive neurons represented $5.5 \%(n=703$ cells $)$ and $18.2 \%$ ( $n=875$ cells), respectively, of the total NGF mRNApositive population. These results, together with that of PARVimmunostaining, emphasize that NGF gene expression is differentially regulated in several subsets of GABAergic hippocampal interneurons. Moreover, we did not find evidence for the expression of NGF mRNA in pyramidal neurons, either in sections innmunolabeled for CALB (which stain some pyramidal neurons in CA1) or in Nissl-stained material (not shown).

We also investigated whether NT3 and BDNF were expressed in GABAergic hippocampal interneurons. In agreement with former data (Ernfors et al., 1990; Rocamora et al., 1992; Lauterborn et al., 1994), the granule cells in the dentate gyrus and the pyramidal neurons in CA2 exhibited positive NT3 hybridization (Fig. 1C). In addition, clusters of autoradiographic silver grains were seen scattered through the several hippocampal layers, especially in the CA3 region. Approximately $16 \%$ of $\mathrm{PARV}$-positive neurons in the hippocampus showed hybridization for NT3 mRNA, most of them being located within or close to the pyramidal layer (Figs. $2 G, H, 4$, Table 1). We found almost no CALB-positive interneurons labeled for NT3 mRNA, but a significant and consistent proportion of CALR-immunoreactive cells displayed NT3 mRNA hybridization (13\%, Table 1). NT3/CALR-positive neurons were more abundant in the CA3 region and in the hilus, but they also occurred in the remaining hippocampal fields (Fig. 4). In both PARV- and CALRimmunoreacted sections, we observed clusters of autoradiographic silver grains over numerous immunonegative neurons (not shown), thus suggesting that other types of interneurons, which are not visualized using calcium-binding protein immunocytochemistry, do express NT3 mRNA.

Sections hybridized for BDNF mRNA showed the characteristic pattern of expression for this neurotrophin (Hofer et al., 1990; Isackson et al., 1991), with the pyramidal and granule cell layers being heavily labeled (Fig. $1 E$ ). As shown with PARV, CALR, or CALB antibodies, however, hippocampal interneurons did not express BDNF mRNA (Fig. 3). Taken together, the present data demonstrate a differential regulation of neurotrophic factors in hippocampal GABAergic neurons, with NGF mRNA being expressed in most PARV-immunoreactive cells and in a subset of CALR- and CALB-positive neurons, and NT3 mRNA expression restricted to a small subpopulation of PARV- and CALRcontaining cells and to interneurons lacking these calcium-binding proteins.

\section{Neurotrophin expression in postsynaptic targets of the GABAergic septohippocampal pathway}

To determine whether hippocampal interneurons expressing NGF and NT3 mRNAs were targets of the GABAergic septohippocam- 

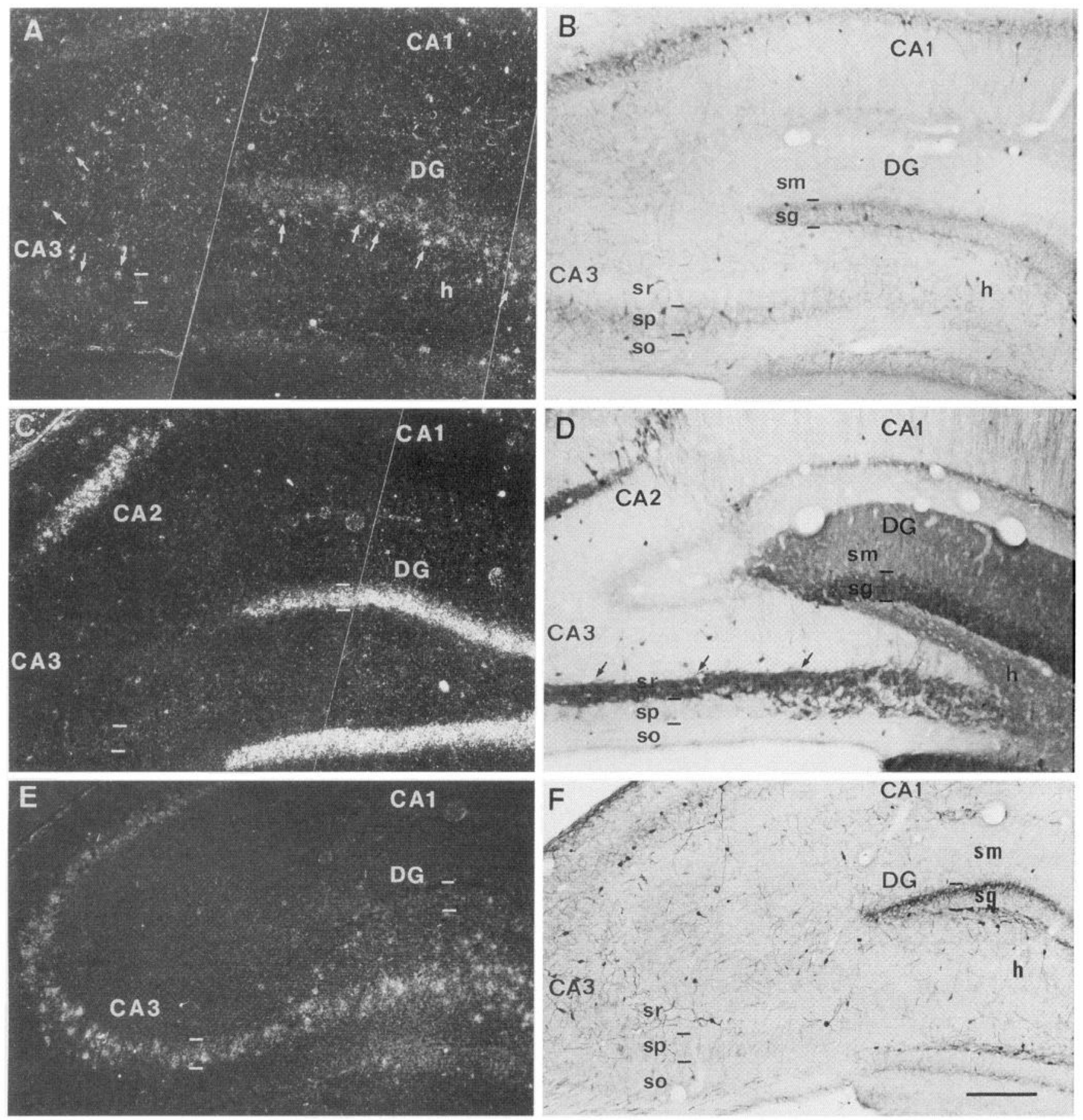

Figure 1. Distribution of NGF, NT3, and BDNF mRNAs in sections from the dorsal hippocampus immunostained for calcium-binding proteins. All pairs of photomicrographs are from the same section except in $C$ and $D . A, B$, Dark-field photomicrograph $(A)$ illustrating NGF mRNA autoradiographic labeling in a PARV-immunoreacted section $(B)$. NGF mRNA hybridization is observed in the dentate gyrus and in cells scattered throughout the hippocampal layers (small arrows). PARV-immunoreactivity is concentrated around the main cell layers. $C$, Dark-field image showing NT3 hybridization signals in the dentate granule cell layer and in the CA2 pyramidal layer. $D$, CALB-immunoreacted section showing immunolabeling in dentate granule cells and their axons, the mossy fibers (small arrows). Some nonpyramidal immunoreactive neurons are observed in several layers. $E$, $F$, A pair of photomicrographs of the same field showing BDNF mRNA hybridization $(E)$ and CALR-immunostaining. $F$, BDNF transcripts are detected in the dentate granule cell layer and in the pyramidal cell layer. CALR-immunopositive nonpyramidal neurons are present in the different hippocampal layers. $C A 1, C A 2, C A 3$, Hippocampal fields; $D G$, dentate gyrus; $h$, hilus; sg, stratum granulare; $s m$, stratum moleculare; $s o$, stratum oriens; $s p$, stratum pyramidale; $s r$, stratum radiatum. Scale bar, $200 \mu \mathrm{m}$.

pal afferents, a triple-labeling approach was undertaken. To label septohippocampal fibers, the anterograde tracer PHAL was injected in the medial septum/diagonal band. Sections were hybridized with radioactive riboprobes and then subjected to a double- immunoperoxidase reaction, allowing the identification of both afferent axons and target neurons. Although the DAB-cobalt reaction product faded slightly during the autoradiographic processing and resulted in a dark brown color, the PHAL-labeled 

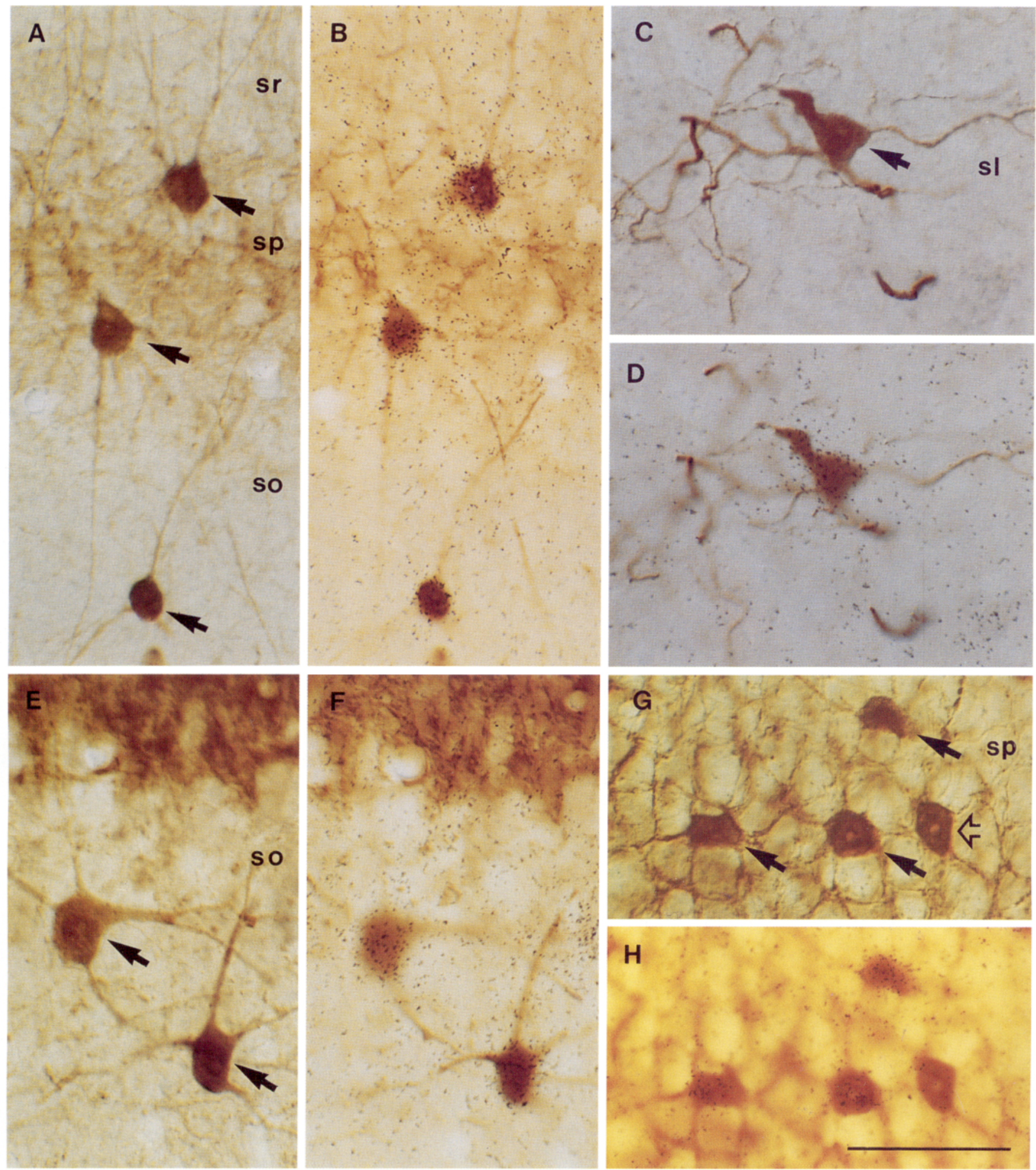

Figure 2. Expression of NGF and NT3 mRNAs in hippocampal interneurons identified with calcium-binding protein immunocytochemistry. Pairs of photomicrographs show the same fields focused at either the plane of the tissue sections or the overlying autoradiographic emulsion. Double-labeled neurons are indicated by arrows. $A, B$, Several PARV-positive neurons express NGF mRNA in the CA1 region. $C, D$, One CALR-immunolabeled neuron in the stratum lucidum $(s l)$ of CA3 is overlaid by autoradiographic silver grains after NGF hybridization. $E$, $F$, Two CALB-positive neurons in stratum oriens ( $s o$ ) of CA3 show positive hybridization for NGF. $G$, $H$, Several PARV-immunopositive neurons in the pyramidal layer ( $s p$ ) of CA3 express NT3 mRNA; open arrow points to a PARV/NT3-negative interneuron. Scale bar, $50 \mu \mathrm{m}$. 

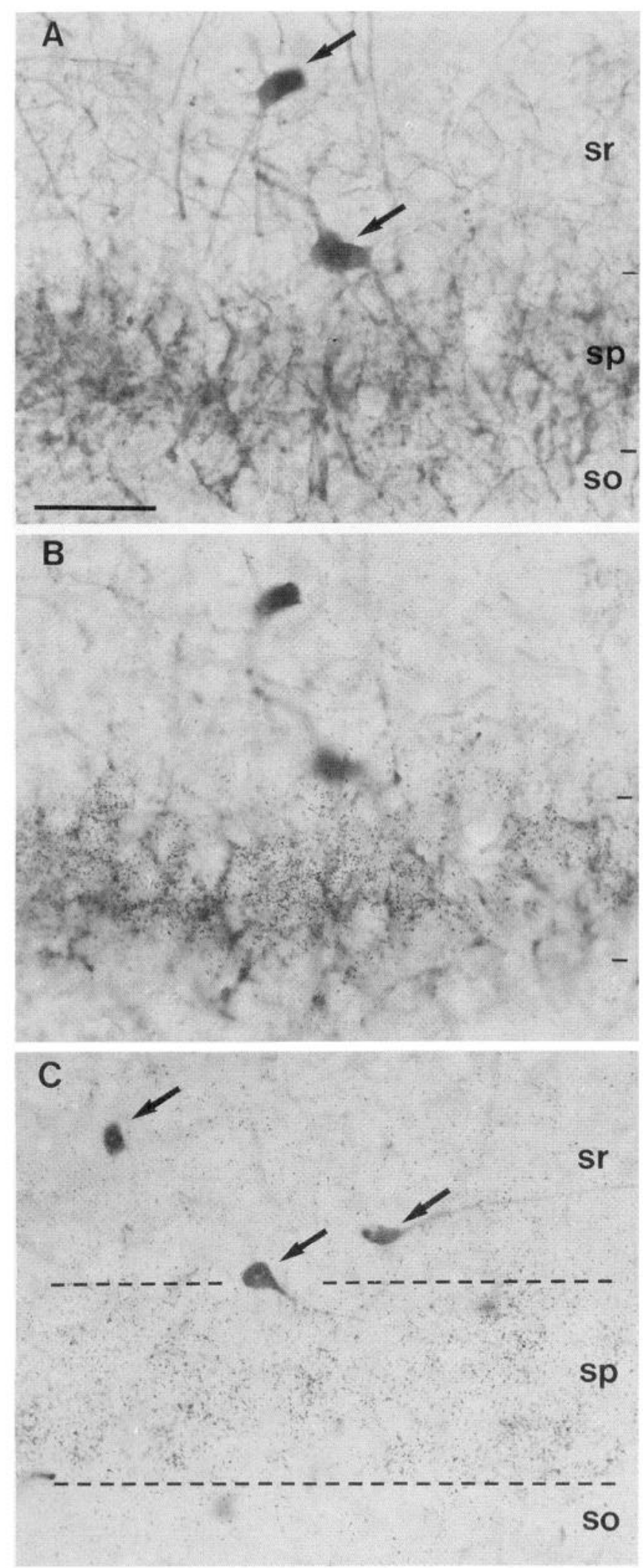

Figure 3. Lack of BDNF expression in hippocampal interneurons. $A, B$, Pair of photomicrographs illustrating PARV-positive interneurons (arrows in $A$ ) in the CA3 region, which are unlabeled with the BDNF riboprobe (B). $C$, Several CALR-positive interneurons (arrows) in the CA3 region show negative hybridization for BDNF mRNA; dashed lines label the pyramidal layer $(s p)$. Notice the dense hybridization signals in the pyramidal layer. $s r$, Stratum radiatum; so, stratum oriens. Scale bar, $50 \mu \mathrm{m}$. fibers were clearly discernible on the basis of their dark color and the typical pericellular arrangement and size of the terminal axons (Fig. 5).

As described elsewhere (Freund and Antal, 1988; Acsàdy et al., 1993), two types of PHAL-labeled fibers could be distinguished. One group of axons was very thin and varicose, displaying numerous small "en passant" boutons $(0.3-0.8 \mu \mathrm{m}$ in diameter) at regular spacing, corresponding to the cholinergic fibers. The GABAergic septohippocampal fibers, the second type of PHALlabeled axons, were easily identified by their distinctive morphology, with thick fibers having clusters of large axon terminals (0.5-2 $\mu \mathrm{m})$. As seen in double-immunostained material, these clusters of boutons typically formed basket-like, pericellular arrays around the somata and dendrites of GABAergic interneurons (Fig. 5). Previous electron microscopic studies have demonstrated that these large boutons form GABAergic synapses on their target cells (Freund and Antal, 1988; Gulyás et al., 1990).

The hybridization patterns for NGF, NT3, and BDNF mRNAs in this material did not differ from sections obtained from animals that had not been injected with PHAL, either in the distribution or in the intensity of autoradiographic signals. This indicates that possible changes in the expression of neurotrophic factors caused by surgery or iontophoresis (Ballarín et al., 1991) are undetectable at the survival times used here. As expected, virtually every PARV-positive neuron in the dentate gyrus, hilus, and CA3 that was surrounded by PHAL-labeled axon terminals (Figs. $5 A, B, 6$ ), and thus receiving input from GABAergic septohippocampal fibers, displayed positive hybridization for NGF mRNA ( $86-95 \%$, Table 1), the percentage being lower in CA1 (75\%). In addition, there were NGF/PARV-positive neurons that were not contacted by PHAL-labeled baskets; this may be attributable to the fact that only a fraction of septohippocampal axons were filled by our PHAL injections.

In CALB-immunoreacted sections, up to $59 \%$ of the immunopositive neurons contacted by PHAL-labeled boutons displayed NGF mRNA hybridization (Figs. 5E,F, 6; Table 1). Considering that CALB/NGF-positive neurons represent only $24 \%$ of the total CALB-positive population, the above data indicate that GABAergic septohippocampal fibers have a preference for terminating on CALB/NGF-positive cells, compared with CALB/NGF-negative neurons. The same holds true, although markedly less, for PHALpositive baskets terminating around CALR-immunoreactive neurons $(39 \%$ vs $23 \%$, Table 1 ; Figs. $5 C, D, 6)$. Moreover, such a preference was observed consistently in the different hippocampal subfields, for both CALB and CALR (Table 1). GABAergic septohippocampal, PHAL-labeled baskets terminating onto CALR- and CALB-immunoreactive neurons that were NGF mRNA-negative were present mainly in the stratum radiatum of the hippocampus proper (Fig. 6), suggesting that they might belong to particular subpopulations of interneurons. These results show that GABAergic septohippocampal fibers have a preference for terminating on NGF mRNA-positive interneurons displaying PARV-, CALB- or CALR-immunoreactivities.

As described above, there were PHAL-labeled baskets around both immunostained and immunonegative neurons that did not express NGF mRNA. To ascertain whether some of these neurons might express NT3 or BDNF mRNAs, PHAL-labeled sections were also hybridized for these neurotrophins. Consistent with our double-labeling observations, PHAL-positive baskets were observed terminating on CALB/NT3-positive neurons only very exceptionally. In contrast, $23 \%$ and $11 \%$ of the PARV- and CALRimmunoreactive neurons that were innervated by PHAL-labeled 

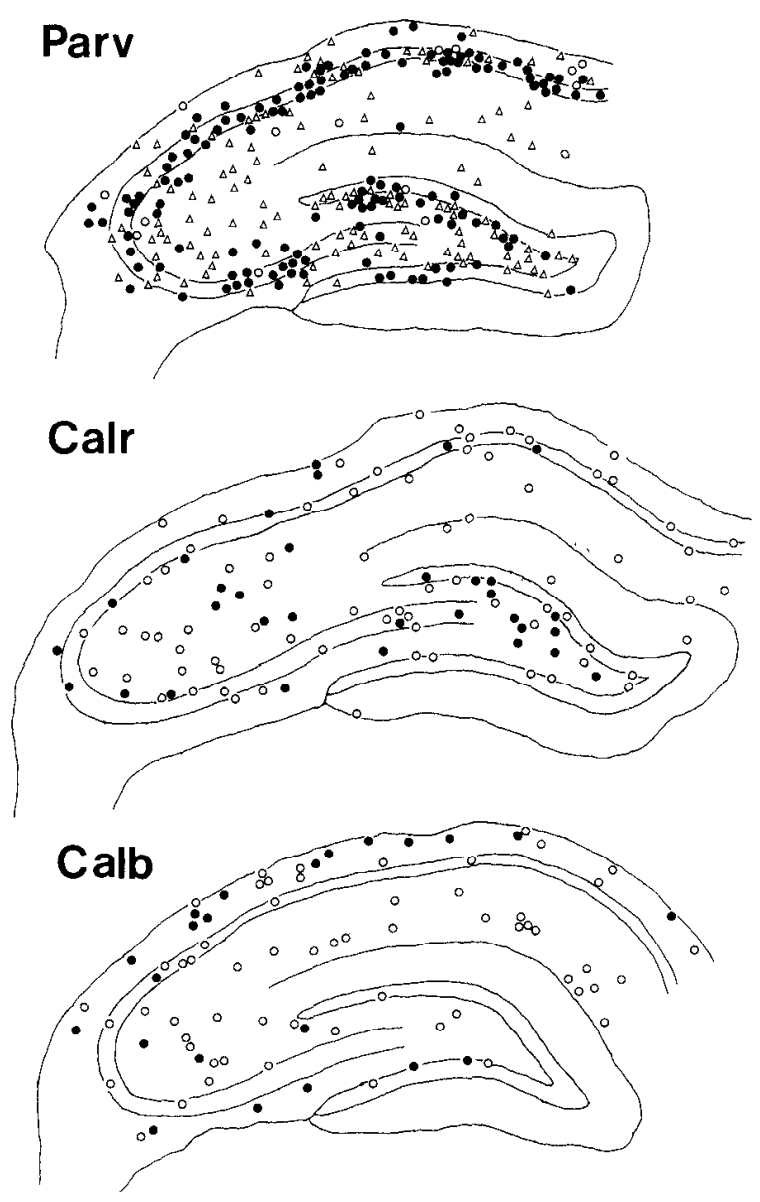

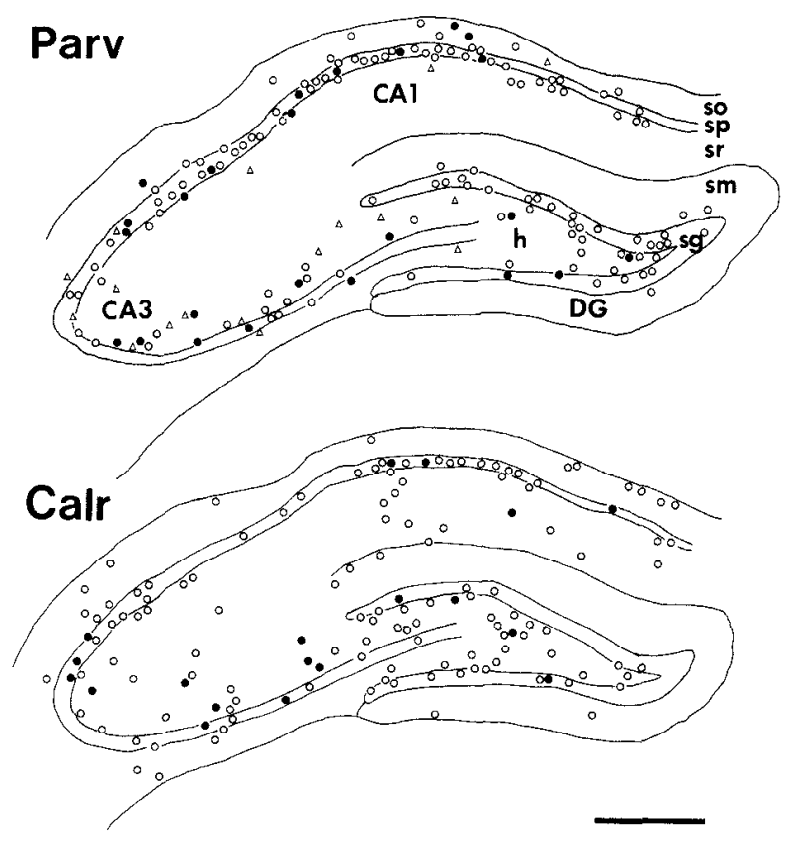

- $\mathrm{CBP}+/ \mathrm{NT3}+$

$\circ \mathrm{CBP}+/ \mathrm{NT3}-$

$\triangle$ Parv - / NT3 +

\section{- $\mathrm{CBP}+/ \mathrm{NGF}+$ \\ - $\mathrm{CBP}+/ \mathrm{NGF}$ - \\ $\triangle$ Parv - / NGF +}

Figure 4. Camcra lucida drawings from dorsal hippocampal sections illustrating the distribution of nonpyramidal neurons immunoreactive for the calcium-binding proteins (CBP) PARV, CALB, and CALR, expressing NGF (left) and NT3 (right) transcripts. Double-labeled cells are represented by filled circles. Immunoreactive neurons showing no NGF mRNA hybridization signal are indicated by open circles. Triangles in the PARV-immunoreacted section (top, to the left) indicate the distribution of NGF-positive/PARV-negative neurons. Plots represent the distribution of cells within one tissuc section. $C A 1, C A 3$, Hippocampal fields; $D G$, dentate gyrus; $h$, hilus; sg, stratum granulare; sm, stratum moleculare; so, stratum oriens; sp, stratum pyramidale; $s r$, stratum radiatum. Scale bar, $500 \mu \mathrm{m}$.

boutons were overlaid by silver grains, indicating that some GABAergic septohippocampal fibcrs terminate on NT3 mRN $\Lambda_{-}^{-}$ expressing interneurons (Fig. 5G,H; Table 1). Such triple-labeled, NT3-positive neurons were particularly frequent in the stratum radiatum of CA3 and in the stratum oriens of CA1 (Fig. 6). No GABAergic septohippocampal fibers were seen to terminate around neurons showing positive hybridization for BDNF mRNA.

\section{DISCUSSION}

\section{NGF mRNA is differentially expressed in distinct} subsets of hippocampal interneurons

An essential step in unraveling the functions of neurotrophic factors is to determine which neuronal subsets express each neu- rotrophin and to establish their association with specific afferent systems (Davics, 1994). Neurotrophic factors are expressed at high levels in the hippocampal region (Gall and Isackson, 1989; Ernfors et al., 1990, 1991; Hofer et al., 1990; Isackson et al., 1991; Gall et al., 1991; Rocamora et al., 1992, 1994; Lauterborn et al., 1994). By taking advantage of the simple, laminated structure of the hippocampus, it has been concluded that dentate granule cells coexpress variable amounts of transcripts encoding for NGF, BDNF, and NT3. In addition, most pyramidal neurons express BDNF mRNA, whereas NT3 transcripts are localized exclusively to a subset of pyramidal neurons in the CA2. In contrast, the low density and scarcity of hybridization signals for NGF mRNA in 

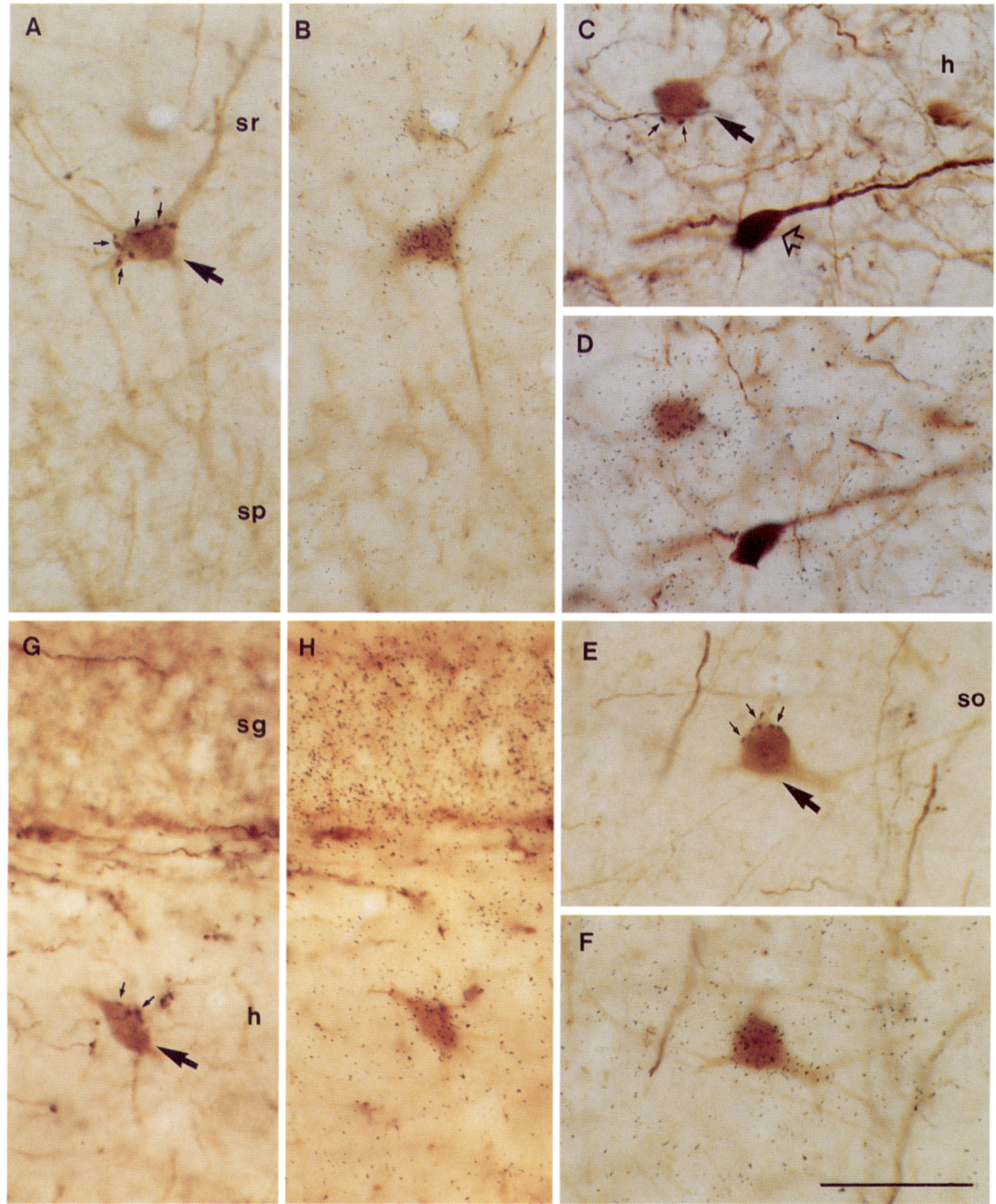

Figure 5. Expression of NGF and NT3 mRNAs in hippocampal interneurons receiving GABAergic septohippocampal input after PHAL injections in the septum. Triple-labeled neurons are indicated by large arrows. $A, B$, A PARV-positive neuron in stratum radiatum ( $s r$ ) of the CA1 region is contacted by several PHAL-labeled, GABAergic septohippocampal boutons forming a pericellular array (small arrows), and it expresses NGF mRNA. $C$, $D$, Expression of transcripts encoding for NGF in a CALR-positive hilar neuron $(h)$ receiving input from GABAergic septohippocampal axons (small arrows). A CALR-positive neuron not innervated by GABAergic fibers is lacking NGF mRNA (open arrow). E, $F$, A triple-labeled, CALB-positive neuron in stratum oriens (so) of CA3 expresses NGF mRNA. $G, H$, Expression of NT3 mRNA in a PARV-positive interneuron in the hilar region of the dentate gyrus is surrounded by PHAL-labeled boutons (small arrows) in a basket-like fashion. Notice the dense NT3 hybridization in the granule cell layer (sg). $s p$, Stratum pyramidale. Scale bar, $50 \mu \mathrm{m}$. 


\section{NGF}

PHAL
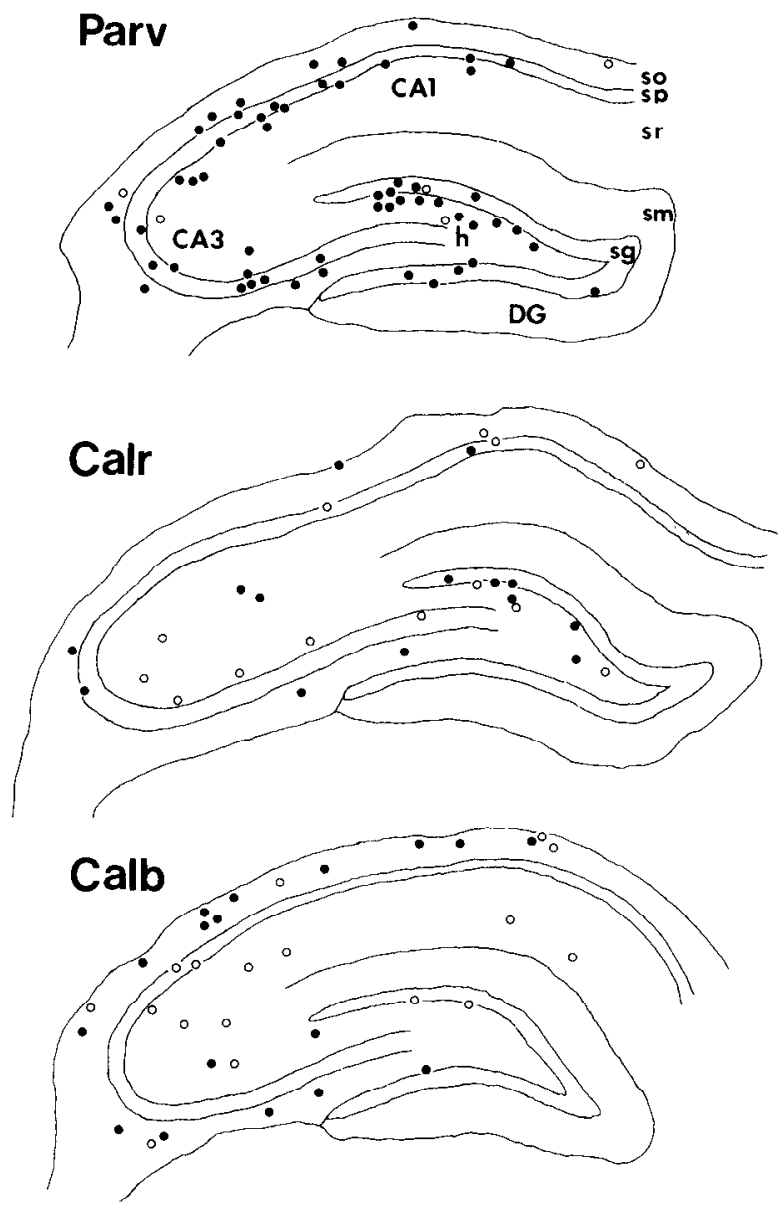

$-\mathrm{CBP}+/ \mathrm{PHAL}+/$ NGF +
$\circ \mathrm{CBP}+/ \mathrm{PHAL}+/$ NGF -
NT3

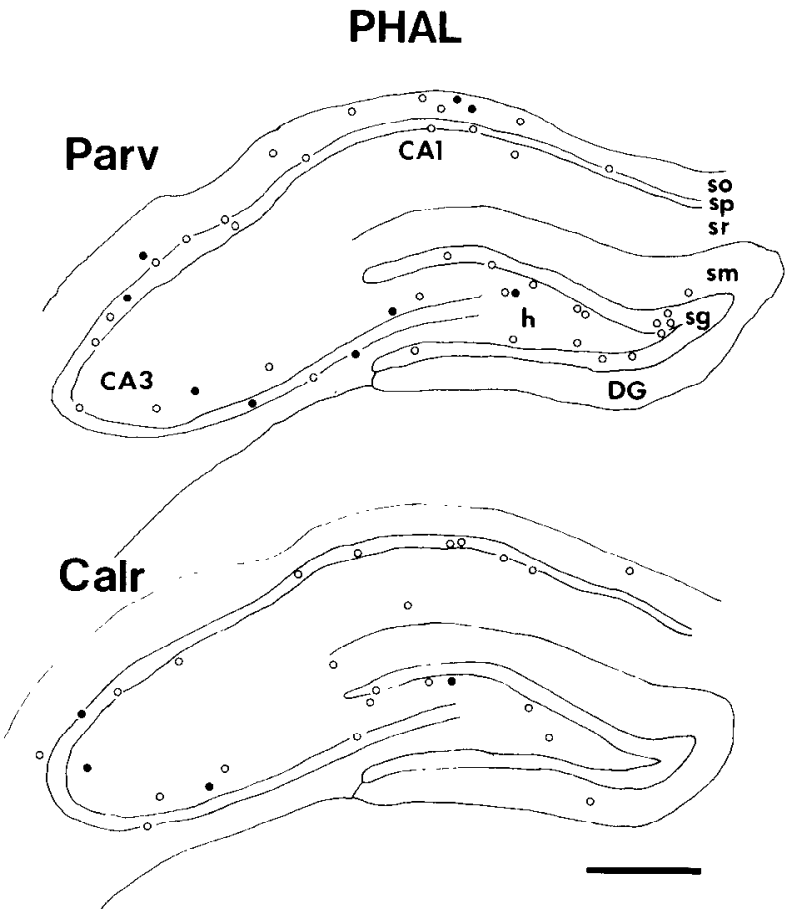

- $\mathrm{CBP}+/ \mathrm{PHAL}+/ \mathrm{NT3}+$

- $\mathrm{CBP}+/ \mathrm{PHAL}+/ \mathrm{NT3}$ -

Figure 6. Camera lucida drawings showing the distribution of triple-labeled cells (circles) innervated by PHAL-labeled fibers that express either NGF (left) or NT3 (right), and one of the three calcium-binding proteins $(C B P)$. The distribution of neurons showing calcium-binding protein immunostaining and PHAL-labeling but not expression of neurotrophins is indicated by open circles. Plots represent the distribution of cells within one tissue section, except for the CALB-immunoreacted section (two sections). Abbreviations as in Figure 4. Scale bar, $500 \mu \mathrm{m}$.

the pyramidal layer have led to controversial data regarding whether hippocampal pyramidal cells express transcripts for this neurotrophin. Using a double in situ hybridization technique, a recent study has shown that $>90 \%$ of hippocampal neurons expressing NGF mRNA also expressed transcripts for the GABA biosynthetic enzyme glutamic acid decarboxylase (Lauterborn et al., 1993). Our results indicating that GABAergic interneurons identified by calcium-binding protein immunocytochemistry exhibit NGF mRNA hybridization agree with this observation. In addition, we show that NGF is differentially expressed in distinct subsets of hippocampal interneurons and that a small subset of these neurons express NT3 mRNA.
Our results show that most PARV-immunoreactive interneurons ( $82 \%$ ) express NGF mRNA. The actual percentage may be even higher, because NGF mRNA-expressing neurons with the somata cut at the bottom of the tissue section were probably falsely considered negative, so that virtually every PARVimmunoreactive neuron in the hippocampus may be NGFpositive. In contrast, only $23-24 \%$ of hippocampal interneurons that are immunoreactive for CALB and CALR express NGF. Furthermore, double-labeled, CALB- and CALR-positive neurons have characteristic distribution patterns, being concentrated in the hilus and the stratum oriens and radiatum, which indicates that they might belong to a unique immunoreactive subpopula- 
Table 1. Percentages of interneurons expressing NGF and NT3 and of triple-labeled cells in the different hippocampal regions

\begin{tabular}{|c|c|c|c|c|c|c|c|c|c|c|}
\hline \multirow[b]{2}{*}{ NGF } & \multicolumn{2}{|c|}{ DG } & \multicolumn{2}{|c|}{$\mathrm{H}$} & \multicolumn{2}{|c|}{ CA3 } & \multicolumn{2}{|c|}{ CA1 } & \multicolumn{2}{|c|}{ TOTAL } \\
\hline & $\%$ & $(n)$ & $\%$ & $(n)$ & $\%$ & $(n)$ & $\%$ & (n) & $\%$ & $(n)$ \\
\hline PARV & 82.6 & (201) & 93.8 & $(130)$ & 81.3 & $(487)$ & 80.0 & (509) & 81.8 & (1327) \\
\hline PARV+PHAL & 95.2 & $(42)$ & 94.6 & $(56)$ & 86.3 & $(175)$ & 75.2 & (105) & 85.5 & (378) \\
\hline CALR & 5.2 & (134) & 28.3 & (159) & 31.5 & $(355)$ & 17.0 & (270) & 23.0 & (918) \\
\hline CALR + PHAL & 31.3 & (16) & 41.9 & $(37)$ & 53.3 & $(78)$ & 27.3 & (33) & 38.8 & (164) \\
\hline CALB & 9.0 & (22) & 28.6 & (28) & 33.2 & $(241)$ & 16.0 & $(250)$ & 24.0 & (541) \\
\hline CALB + PHAL & & (3) & 55.5 & (9) & 60.5 & $(119)$ & 41.2 & (51) & 59.0 & (182) \\
\hline \multicolumn{11}{|l|}{ NT3 } \\
\hline PARV & 5.0 & (179) & 18.4 & (125) & 18.1 & $(276)$ & 19.2 & (416) & 16.3 & (996) \\
\hline $\mathrm{PARV}+\mathrm{PHAL}$ & 9.3 & (43) & 26.4 & (53) & 26.1 & (73) & 30.6 & (111) & 23.3 & $(280)$ \\
\hline CALR & 0.8 & $(122)$ & 5.6 & (177) & 24.1 & (356) & 9.9 & (342) & 13.1 & (997) \\
\hline CALR+PHAL & & (16) & 7.7 & (46) & 25.8 & (71) & 1.8 & (57) & 11.2 & $(190)$ \\
\hline CALB & & (36) & & (39) & 1.9 & $(204)$ & & (232) & 0.8 & $(511)$ \\
\hline CALB + PHAL & & (3) & & (18) & 2.5 & $(80)$ & & (55) & 1.3 & (156) \\
\hline
\end{tabular}

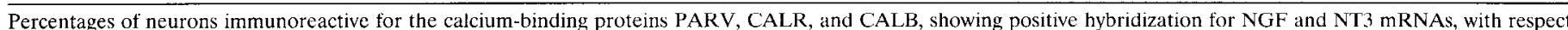

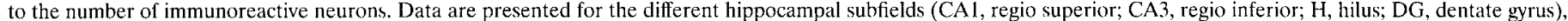

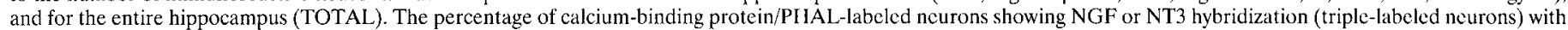
regard to the number of double-labeled cells (calcium-binding protein/PHAL-positive) is also indicated. The number of cells counted is indicated in parentheses.

tion. Our results also show that all together, the interneurons immunostained for PARV (71\%), CALB (5\%), and CALR $(18 \%)$ account for nearly $94 \%$ of the total NGF-positive population in the hippocampus, with the exception of granule cells. These data support the conclusion that interneurons are a major source of NGF production in the hippocampus and that hippocampal interneurons that are not visualized using calcium-binding proteins as markers (e.g., those containing certain neuropeptides; M. Pascual, N. Rocamora, L. Acsàdy, T. F. Freund, E. Soriano, unpublished data) represent only a minor population.

The calcium-binding proteins PARV, CALB, and CALR are present in functionally different classes of hippocampal interneurons (Katsumaru at al., 1988; Soriano et al., 1990; Gulyás et al., 1991, 1993a; Miettinen et al., 1992; Han et al., 1993; Soriano and Frotscher, 1993a; Buhl et al., 1994; Miles et al., 1995; Soltesz et al., 1995). Thus, PARV-positive cells are responsible for perisomatic inhibition controlling the pattern of output of principal cells, whereas CALB-immunorcactive neurons produce dendritic inhibition regulating the efficacy and plasticity of synaptic input. In addition, both subsets of interneurons fire at different frequency and mediate their inhibitory actions via distinct GABA receptors. CALR-positive cells seem to be involved in the synchronization of inhibitory cell activity (Gulyás et al., 1995). We can only speculate about the mechanisms that could be responsible for the synthesis of NGF in some interneurons but not in others. Because NGF expression is regulated by synaptic activity (Zafra et al., 1990, 1991; Ernfors et al., 1991; Gall et al., 1991; Rocamora et al., 1992, 1994), however, it is possible that the expression of NGF mRNAs mostly in PARV-positive interneurons may be determined by the highly active, "fast-spiking" electrophysiological behavior of this particular population.

\section{Subsets of hippocampal interneurons express NT3 but not BDNF mRNA}

In addition to expressing NGF, some hippocampal interneurons express NT3 mRNA, whereas BDNF mRNA is absent from nonpyramidal cells. The lack of BDNF expression in nonpyramidal neurons agrees with studies reporting localization of BDNF
mRNA in pyramidal and granule cells (Hofer et al., 1990; Isackson et al., 1991). Furthermore, findings in transgenic micc lacking the BDNF gene and studies reporting TrkB expression in hippocampal interneurons indicate that these neurons are dependent on the trophic support of BDNF (Jones et al., 1994; Marty et al., 1996).

NT3 mRNA is expressed in a small percentage of hippocampal interneurons (16 and 13\% of PARV- and CALR-positive cells, respectively). Although we have not performed double-labeling experiments, the high number of NGF/PARV-positive neurons indicates that NT3 and NGF mRNAs are likely to be coexpressed in some PARV-positive neurons. Additional analyses are needed to ascertain whether expression of NT3 and NGF mRNAs may overlap in CALR-immunoreactive neurons. Finally, there were many NT3 mRNA-positive/CALR-negative neurons in the plexiform layers, where PARV-immunoreactive neurons are absent, indicating that additional classes of interneurons that do not display calcium-binding proteins are likely to synthesize NT3.

\section{Hippocampal interneurons expressing NGF and NT3 are preferential targets of the GABAergic septohippocampal pathway}

Neurotrophic factors are believed to be involved in the formation, maintenance, and plasticity of specific afferent connections, and in the survival of afferent neurons. Depending on their laminar location, the different hippocampal interneurons receive distinct patterns of innervation from intrinsic and extrinsic afferents. For instance, interneurons in the hilus and stratum lucidum receive their principal input from the mossy fibers (Gulyás et al., 1992; Soriano and Frotscher, 1993b), and GABAergic neurons whose dendrites are restricted to other layers, such as the stratum lacunosum moleculare or the dentate molecular layer, receive their major inputs from the entorhinal cortex or the commissural/ associational system (Lacaille and Schwartzkroin, 1988; Soriano et al., 1990; Gulyás et al., 1991). Although NT3 might be involved in the specification of the major afferent systems to the hippocampus, the wide regional and laminar distribution of interneurons expressing NGF, together with the lack of Trk transcription in the 
entorhinal cortex and hippocampus itself (Gibbs and Pfaff, 1994), does not support an involvement for this neurotrophic factor in the establishment of the main afferent connections to interneurons. In contrast, the GABAergic septohippocampal pathway shows a high degree of synaptic specificity, with afferent fibers terminating almost exclusively onto different subsets of hippocampal GABAergic interneurons (Freund and Antal, 1988; Gulyás et al., 1990), indicating that the formation of this connection requires the involvement of highly specific cell-to-cell interactions. Here we studied whether hippocampal GABAergic cells expressing neurotrophins were postsynaptic targets of GABAergic septohippocampal axons. Our results show that virtually all PARVimmunoreactive interneurons innervated by GABAergic septohippocampal afferents express NGF mRNA. A good correlation is also observed for $C \Lambda L R$ - and $C \Lambda L B$-positive interneurons, with roughly half the number of PHAL-labeled septohippocampal baskets terminating onto immunoreactive neurons expressing NGF. Taking into account that the number of PARVimmunoreactive interneurons in the hippocampus is at least threefold the number of CALR- and CALB-positive interneurons (our unpublished observations; also see Celio, 1990; Gulyás et al., 1991, Miettinen et al., 1992), we conclude that a large proportion of GABAergic septohippocampal fibers $(\sim 80 \%)$ terminate on NGF mRNA-expressing hippocampal interneurons.

We found that some GABAergic septohippocampal fibers also terminate on interneurons expressing NT3 mRNA. NT3 is transported retrogradely by some septohippocampal neurons after injections of this neurotrophin into the hippocampus (DiStephano et al., 1992), and its specific receptor, TrkC, is expressed in the septal region (Merlio et al., 1992; Lamballe et al., 1994). There could be two different types of G $\Lambda \mathrm{B} \Lambda$ ergic septohippocampal neurons selectively contacting either NGF- or NT3-expressing hippocampal interneurons. It is equally possible that the same GABAergic septohippocampal neuron could form connections simultancously onto NGF- and NT3-producing cells. Experimental studies after axotomy or target ablation have not provided evidence for a role of NT3 as a trophic factor for septohippocampal neurons (Burke et al., 1994), although the involvement of NT3 in the specification of the septohippocampal connections or in the modulation of synaptic plasticity remains to be elucidated. In addition, a few PHAL-labeled baskets were observed around interneurons that do not express NGF or NT3. For instance, the CALB-positive population in the stratum radiatum and lacunosum moleculare in CA1 do not express NGF or NT3 mRNAs, although they receive afferent input from GABAergic septohippocampal axons (Freund and Antal, 1988). We cannot rule out at present that these particular populations of interneurons might synthesize other neurotrophic factors, such as NT4.

\section{Possible functions of NGF and NT3 in the GABAergic septohippocampal pathway}

One possible function for NGF in the GABAergic septohippocampal pathway could be the establishment and maturation of this connection and its maintenance in adults. The high correlation between the timing of formation of the GABAergic septohippocampal pathway and the onset of NGF expression in the hippocampus (Linke and Frotscher, 1993; Lauterborn et al., 1994; Supèr and Soriano, 1994; Li et al., 1995), as well as studies indicating the presence of the low-affinity NGF receptor in developing GABAergic septal neurons (Arimatsu and Miyamoto, 1989, 1991), all favor this hypothesis. Moreover, GABAergic septohippocampal neurons show high-affinity binding for NGF in vitro
(Dreyfus et al., 1989) and are likely to transport NGF retrogradely from the target hippocampal region (Cooper et al., 1994). In the adult, however, GABAergic neurons do not express the lowaffinity p75 receptor nor the high-affinity Trk receptor (Batchelor et al., 1989; Kiss et al., 1993; Steininger et al., 1993; Gibbs and Plalf, 1994; Sovreviela el al., 1994; Holtzinan el al., 1995). This suggests that the actions of NGF on GABAergic neurons may be mediated by mechanisms independent of the high-affinity NGF receptor, perhaps involving TrkB and TrkC receptors (Horvath et al., 1993; Knipper et al., 1993, 1994; Chao and Hempstead, 1995; Itoh et al., 1995). In line with this, GABAergic septohippocampal neurons express both TrkB and TrkC (M. Pascual, N. Rocamora, E. Soriano, unpublished data; also see Merlio et al., 1992; Ringstedt et al., 1993; Lamballe et al., 1994). Clearly, additional studies are needed to ascertain whether neurotrophins play a role in the developmental specification and maintenance of the GABAergic septohippocampal connections.

Recent studies provide evidence that neurotrophic factors acting directly on presynaptic terminals can potentiate developing neuromuscular synapses (Lohof et al., 1993) and enhance both synaptic strength at mature Schaffer collateral-CA1 synapses (Kang and Schuman, 1995) and the release of acetylcholine from hippocampal synaptosomes (Knipper et al., 1994). The GABAergic septohippocampal pathway has a profound effect on the electrical activity of the hippocampus by inhibiting hippocampal interneurons, which in turn produces a strong disinhibition and/or synchronization of principal cells (Tóth et al., 1995). It is tempting to speculate that NGF produced and released by interneurons may be one of the mechanisms that mediates the high efficiency of GABAergic septohippocampal synapses.

Finally, the present results, together with the multiple reciprocal interactions between the medial septum and the hippocampus (Tóth et al., 1993), provide a basis for understanding the complex regulation of NGF gene expression in the hippocampus. Activation of cholinergic septohippocampal afferents is known to increase NGF mRNA expression in the hippocampus (Lindefors et al., 1992, Berzaghi et al., 1993; Freedman et al., 1993). The finding that acetylcholine acting through cholinergic-muscarinic receptors activates hippocampal inhibitory neurons, whereas it decreases electrical activity in principal cells (Brunner and Misgeld, 1994), is consistent with the notion that the above-mentioned NGF upregulation is mediated by hippocampal interneurons. In turn, activation of the GABAergic septohippocampal pathway is likely to downregulate NGF production in hippocampal interneurons, because GABA decreases NGF gene expression (Zafra et al., 1991). Thus, production of NGF by interneurons may be under a dual and opposing influence of the cholinergic and $\mathrm{G} \wedge \mathrm{B} \Lambda$ ergic septohippocampal systems. In addition, because NGF transcription is dependent on neuronal activity (Zafra et al., 1990, 1991; Ernfors et al., 1991), expression of NGF in interneurons is likely to reflect and be under the control of the average activity of large principal cell populations in the hippocampus. Interneurons are ideally suited for this task, because each interneuron receives a convergent input from large numbers of principal cells (Gulyás et al., 1993b). Thus, NGF production by interneurons acting as "sensors" of hippocampal activity might also be used to control the overall density of cholinergic afferents and to promote plastic changes and sprouting of this system, in response to increased hippocampal activity such as in learning and memory processes.

In conclusion, the present results showing that particular subsets of hippocampal interneurons are a major source of NGF production, and some interneurons also express NT3, indicates 
that under physiological conditions, activation of synaptic inputs onto these neurons is likely to play a prominent role in regulating the production of neurotrophic factors in the hippocampus. Moreover, the finding that NGF- and NT3-expressing interneurons are preferential targets of the GABAergic septohippocampal pathway suggests a role for these neurotrophic factors in the formation and physiological functioning of this connection, in addition to the well known effects of neurotrophins on cholinergic septohippocampal neurons.

\section{REFERENCES}

Acsàdy L, Halasy K, Freund TF (1993) Calretinin is present in nonpyramidal cells of the rat hippocampus. III. Their inputs from the median raphe and medial septal nucleus. Neuroscience 52:829-841.

Alderson RE, Alterman AL, Barde Y-A, Lindsay RM (1990) Brainderived neurotrophic factor increases survival and differentiated functions of rat septal cholinergic neurons in culture. Neuron 5:297-306

Arimatsu Y, Miyamoto M (1989) Co-localization of NGF receptor immunoreactivity and $\left({ }^{3} \mathrm{H}\right) \mathrm{GABA}$ uptake activity in developing rat septum/diagonal band neurons in vitro. Neurosci Lett 99:39-43.

Arimatsu Y, Miyamoto M (1991) Survival-promoting effect of NGF on in vitro septohippocampal neurons with cholinergic and GABAergic phenotypes. Dev Brain Res 58:189-201.

Ballarín M, Ernfors P, Lindefors N, Persson H (1991) Ilippocampal damage and kainic acid injection induce a rapid increase in mRNA for BDNF and NGF in the rat brain. Exp Neurol 114:35-43.

Barde YA (1989) Trophic factors and neuronal survival. Neuron 2:1525-1534

Batchelor PE, Armstrong DM, Blaker SN, Gage FH (1989) Nerve growth factor receptor and choline acetyltransferase colocalization in neurons within the rat forebrain: response to Fimbria-Fornix transection. J Comp Neurol 284:187-204.

Berzaghi M, Cooper J, Castrén E, Zafra F, Sofroniew M, Thoenen H, Lindholm D (1993) Cholinergic regulation of brain-derived neurotrophic factor (BDNF) and nerve growth factor (NGF) but not neurotrophin-3 (NT-3) mRNA levels in the developing rat hippocampus. J Neurosci 13:3818-3826.

Brumner H, Misgeld U (1994) Muscarinic amplification of fast excitation in hilar neurons and inhibition in granule cells in the guinea-pig hippocampus. J Physiol (Lond) 480:513-526.

Buhl E, Halasy K, Somogyi P (1994) Diverse sources of unitary inhibitory postsynaptic potentials and the number of synaptic release sites. Nature 368:823-828.

Burke MA, Mobley WC, Cho J, Stanley JW, Ronald ML, Elliott JM, Kordower JH (1994) Loss of developing cholinergic basal forebrain neurons following excitotoxic lesions of the hippocampus: rescue by neurotrophins. Exp Neurol 130:178-195.

Celio MR (1990) Calbindin D-28k and parvalbumin in the rat nervous system. Neuroscience 35:375--475.

Chao MV, Hempstead BL (1995) p75 and TrK: a two receptor system. Trends Neurosci 18:321-326.

Cooper JD, Lindholn D, Sofroniew MV (1994) Reduced transport of ${ }^{125}$ I] nerve growth factor by cholinergic neurons and down-regulated TrKA expression in the medial septum of aged rats. Neuroscience 62:625-629.

Crowley C, Spencer SD, Nishimura MC, Chen KS, Pitts-Meek S, Armanini MP, Ling LH, McMahon SB, Shelton DL, Levinson AD, Philips HS (1994) Mice lacking nerve growth factor display perinatal loss of sensory and sympathetic neurons yet develop basal forebrain cholinergic neurons. Cell 76:1001-1011.

Davies AM (1994) Switching neurotrophin dependence. Curr Biol $4: 273-276$.

de Lecea L, Soriano E, Criado JR, Steffensen SC, Henriksen SJ, Sutcliffe JG (1994) transcripts encoding a neural membrane CD26 peptidaselike protein are stimulated by synaptic activity. Mol Brain Res 25:286-296

DiStefano PS, Friedman B, Radziejewski C, Alexander C, Boland P, Schick CM, Lindsay RM, Wiegand SJ (1992) The neurotrophins BDNF, NT-3, and NGF display distinct patterns of retrograde axonal transport in peripheral and central neurons. Neuron 8:983-993.

Dreyfus CF, Bernd P, Martínez HJ, Rubin SJ, Black IB (1989) GABAergic and cholinergic neurons exhibit high-affinity nerve growth factor binding in rat basal forebrain. Exp Neurol 104:181-185.
Ernfors P, Bengzon J, Kokaia Z, Persson H, Lindvall O (1991) Increased levels of messenger RNAs for neurotrophic factors in the brain during kindling epileptogenesis. Neuron 7:165-176.

Frnfors P, I.ee K-F, Jaenisch R (1994) Mice lacking hrain-derived nelrotrophic factor develop with sensory deficits. Nature 368:147-150.

Ernfors P, Wetmore C, Olson L, Persson H (1990) Identification of cells in rat brain and peripheral tissucs cxpressing mRNA for members of the nerve growth factor family. Neuron 5:511-526.

Freedman R, Wetmore C, Strömberg I, Leonard S, Olson L (1993) O-Bungarotoxin binding to hippocampal interneurons: immunocytochemical characterization and effects on growth factor expression. J Neurosci 13:1965-1975.

Freund TF (1989) GABAergic septohippocampal neurons contain parvalbumin. Brain Res 478:375-381.

Freund TF, Antal M (1988) GABA-containing neurons in the septum control inhibitory interneurons in the hippocampus. Nature 336:170-173

Frotscher M, Leranth C (1985) Cholinergic innervation of the rat hippocampus as revealed by choline acetyltransferase immunocytochemistry: a combined light and electron microscopic study. J Comp Neurol 239:237-246.

Funakoshi H, Belluardo N, Arenas E, Yamamoto Y, Casabona A, Persson H, Ibáñez CF (1995) Muscle-derived neurotrophin-4 as an activitydependent trophic signal for adult motor neurons. Science 268:1495-1499.

Gall CM, Isackson PJ (1989) Limbic seizures increase neuronal production of messenger RNA for nerve growth factor. Science 245:758-761.

Gall CM, Murray K, Isackson PJ (1991) Kainic acid-induced seizures stimulate increased expression of nerve growth factor mRNA in rat hippocampus. Mol Brain Res 9:113-123.

Gerfen CR, Sawchenko PE (1984) An anterograde neuroanatomical tracing method that shows the detailed morphology of neurons, their axons and terminals: immunohistochemical localization of an axonally transported plant lectin, Phaseolus vulgaris leucoagglutinin (PHA-L). Brain Res 290:219-238.

Gibbs RB, Pfaff DW (1994) In situ hybridization detection of trkA mRNA in brain: distribution, colocalization with $p^{75 N G F R}$ and upregulation by nerve growth factor. J Comp Neurol 341:324-339.

Gulyás AI, Acsàdy L, Hajos H, Freund TF (1995) Specialized interneurons in control of other hippocampal interneurons. 19th Meeting of the European Neuroscience Association, Amsterdam, The Netherlands. Abstract 10.05, p 7.

Gulyás AI, Görcs T, Freund TF (1990) Innervation of diffcrent peptidecontaining neurons in the hippocampus by GABAergic septal afferents. Neuroscience 37:31-44.

Gulyás AI, Miettinen R, Jacobowitz DM, Freund TF (1992) Calretinin is present in non-pyramidal cells of the rat hippocampus. I: A new type of neuron-specifically associated with the mossy fibre system-revealed. Neuroscience 48:1-27.

Gulyás AI, Miles R, Hájos N, Freund TF (1993a) Precision and variability in postsynaptic target selection of inhibitory cells in the hippocampal CA3 region. Eur J Neurosci 5:1729-1751.

Gulyás AI, Miles R, Sík A, Tóth K, Tamamaki N, Freund TF (1993b) Hippocampal pyramidal cells excite inhibitory neurons through a single release site. Nature 366:683-686.

Gulyás AI, Tóth K, Dános P, Freund TF (1991) Subpopulations of GABAergic neurons containing parvalbumin, calbindin D $28 \mathrm{~K}$ and cholecystokinin in the rat hippocampus. J Comp Neurol 312:371-378.

Han Z-S, Buhl EH, Lörinczi Z, Somogyi P (1993) A high degree of spatial selectivity in the axonal and dendritic domains of physiologically identified local-circuit neurons in the dentate gyrus of the rat hippocampus. Eur J Neurosci 5:395-410.

Hartikka J, Hefti F (1988) Development of septal cholinergic neurons in culture: plating density and glial cells modulate the effects of NGF on survival, fiber growth and expression of transmitter-specific enzymes. J Neurosci 8:2967-2985.

Hefti F (1986) Nerve growth factor promotes survival of septal cholinergic neurons after fimbrial transections. J Neurosci 6:2155-2162.

Hofer M, Pagliusi SR, Hohn A, Leibrok J, Barde Y-A (1990) Regional distribution of brain-derived neurotrophic factor RNA in the adult mouse brain. EMBO J 9:2459-2464.

Holtzman DM, Kilbridge J, Li Y, Cunningham ET, Lenn EJ, Clary DO, Reichardt LF, Mobley WC (1995) TrkA expression in the CNS: evidence for the existence of several novel NGF-responsive CNS neurons. J Neurosci 15:1567-1576. 
Horvath CM, Wolven A, Machadeo D, Huber J, Boter L, Benedetti M, Hemstead B, Chao MV (1993) Analysis of the trk NGF receptor tyrosine kinase using recombinant fusion proteins. J Cell Sci Suppl 17:223-228.

Isackson PJ, Huntsman MM, Murray KD, Gall CM (1991) BDNF mRNA Expression is increased in adult rat forebrain after limbic seizures: temporal patterns of induction distinct from NGF. Neuron 6:937-948.

Itoh K, Brachenbury R, Akeson RA (1995) Induction of L1 in PC12 cells by NGF is modulated by cell-cell contact and does not require the high-affinity NGF receptor. J Neurosci 15:2504-2512.

Johnson J, Oppenheim R (1994) Keeping track of changing neurotrophic theory. Curr Biol 4:662-665.

Jones KR, Fariñas I, Backus C, Reichardt LF (1994) Targeted disruption of the BDNF gene perturbs brain and sensory development but not motor neuron development. Cell 76:989-999.

Kang H, Schuman EM (1995) Long-lasting neurotrophin-induced enhancement of synaptic transmission in the adult hippocampus. Science 267:1658-1662.

Katsumaru H, Kosaka T, Weizmann CW, Hama K (1988) Immunocytochemical study of GABAergic neurons containing the calcium binding protein parvalbumin in the rat hippocampus. Exp Brain Res 72:347-362.

Kiss J, Patel AJ, Freund TF (1990) Distribution of septohippocampal neurons containing parvalbumin and choline acetyltransferase in the rat brain. J Comp Ncurol 298:362-372.

Kiss J, Shooter EM, Patel AJ (1993) A low-affinity nerve growth factor receptor antibody is internalized and retrogradely transported selectively into cholinergic neurons of the rat basal forebrain. Neuroscience 57:297-305.

Klein R, Silos-Santiago I, Smeyne RJ, Lira SA, Brambilla R, Bryant S, Zhang L, Snider WD, Barbacid M (1994) Disruption of the neurotrophin-receptor gene trkC eliminates Ia muscle afferents and results in abnormal movements. Nature 368:249-251

Knipper M, Beck A, Rylett J, Breer H (1993) Neurotrophin induced second messenger responses in rat brain synaptosomes. NeuroReport $4: 483-486$

Knipper M, Berzaghi M, Blöchl A, Breer H, Thoenen H, Lindholm D (1994) Positive feedback between acetylcholine and the neurotrophins nerve growth factor and brain-derived neurotrophic factor in the rat hippocampus. Eur J Neurosci 6:668-671.

Knüsel B, Winslow JW, Rosenthal A, Burton LE, Seid DP, Nikolics K, Hefti F (1991) Promotion of central cholinergic and dopaminergic neuron differentiation by brain-derived neurotrophic factor but not neurotrophin-3. Proc Natl Acad Sci USA 88:961-965.

Köhler C, Chan-Palay V, Wu JY (1984) Septal neurons containing glutamic acid decarboxylase immunoreactivity project to the hippocampal region of the rat. Andat Enlbryol (Berl) 169:41-44.

Korsching S (1993) The neurotrophic factor concept: a reexamination. J Neurosci 13:2739-2748.

Kosaka T, Katsumaru H, Hama K, Wu LY, Heizmann CW (1987) GABAergic neurons containing the $\mathrm{Ca}^{++}$-binding protein parvalbumin in the rat hippocampus. Brain Res 419:119-130.

Lacaille JC, Schwartzkroin PA (1988) Stratum lacunosum-moleculare interneurons of hippocampal CA1 region. II. Intrasomatic and intradendritic recordings of local circuit synaptic interactions. J Neurosci 8:1411-1424

Lamballe F, Smeyne RJ, Barbacid M (1994) Developmental expression of trkC, the neurotrophin-3 receptor, in the mammalian nervous system. J Neurosci 14:14-28.

Lauterborn JC, Isackson PJ, Gall CM (1994) Cellular localization of NGF and NT-3 mRNAs in postnatal rat forebrain. Mol Cell Neurosci 5:46-62.

Lauterborn JC, Tran TMD, Isackson PI, Gall CM (1993) Nerve growth factor mRNA is expressed by GABAcrgic neurons in rat hippocampus. NeuroReport 5:273-276.

Leranth C, Frotscher M (1987) Cholinergic innervation of hippocampal GAD- and somatostatin-immunoreactive commissural neurons. J Comp Neurol 261:33-47.

Li Y, Holtzman DM, Kromer LF, Kaplan DR, Chua-Couzens J, Clary DO, Knüsel B, Mobley WC (1995) Regulation of TrkA and ChAT expression in developing rat basal forebrain: evidence that both exogenous and endogenous NGF regulate differentiation of cholinergic neurons. J Neurosci 15:2888-2905.
Lindefors N, Ernfors P, Falkenberg T, Persson H (1992) Septal cholinergic afferents regulate expression of brain-derived neurotrophic factor and $\beta$-nerve growth factor mRNA in rat hippocampus. Exp Brain Res $88: 78-90$

Linke R, Frotscher M (1993) Ontogenesis of the septohippocampal pattern in the rat. A time course analysis using anterograde and retrograde transport of DiI and electron microscopy of identified growth cones. J Comp Neurol 332:69-88.

Lohof AM, Ip NY, Poo M (1993) Potentiation of developing neuromuscular synapses by the neurotrophins NT-3 and BDNF. Nature 363:350-353.

Maisonpierre PC, Belluscio L, Squinto S, Ip NY, Furth ME, Lindsay RM, Yancopoulos GD (1990) Neurotrophin-3: a neurotrophic factor related to NGF and BDNF. Science 347:1446-1453.

Marty S, Carroll $P$, Cellerino A, Castrén E, Staiger V, Thoenen $H$, Lindholm D (1996) Brain-derived neurotrophic factor promotes the differentiation of various hippocampal nonpyramidal neurons, including Cajal-Retzius cells, in organotypic slice cultures. J Neurosci 16:675-687.

Merlio JP, Jaber EM, Persson H (1992) Molecular cloning of rat trk C and distribution of cells expressing messenger mRNAs for members of the trk family in the rat central nervous system. Neuroscience $51: 513-532$

Mettling C, Gouin A, Robinson M, El M'Hamdi H, Camu W, BlochGallego E, Buisson B, Tanaka H, Davies AL, Henderson CE (1995) Survival of newly postmitotic motoneurons is transiently independent of exogenous trophic support. J Ncurosci 15:3128-3137.

Miettinen R, Gulyás AI, Jacobowitz DM, Freund TF (1992) Calretinin is present in non-pyramidal cells of the rat hippocampus. II. Coexistence with other calcium binding proteins and GABA. Neuroscience 48:29-43.

Miles R, Tóth K, Gulyás AI, Hajós N, Freund TF (1995) Different functions for dendritic and somatic inhibitory cells in the hippocampus. J Physiol (Lond) 480:32

Naumann T, Kermer P, Seydewith V, Ortmann R, D'Amato F, Frotscher M (1994) Is there a long-lasting effect of a short-term nerve growth factor application on axotomized rat septohippocampal neurons?. Neurosci Lett 173:213-215.

Naumann T, Peterson GM, Frotscher M (1992) Fine structure of rat septohippocampal neurons. II. A time course analysis following axotomy. J Comp Neurol 325:219-242.

Nitsch R, Soriano E, Frotscher M (1990) The parvalbumin-containing nonpyramidal neurons in the rat hippocampus. Anat Embryol (Berl) $181: 413-425$

Ringstedt T, Lagercrantz H, Persson H (1993) Expression of members of the trk family in the developing postnatal rat brain. Dev Brain Res 72:119-131.

Rocamora N, Massieu L, Boddeke HWGM, Palacios JM, Mengod G (1994) Differential regulation of the expression of nerve growth factor, brain-derived neurotrophic factor and neurotrophin-3 mRNAs in adult rat brain after intrahippocampal injection of quinolinic acid. Mol Brain Res 26:89-98.

Rocamora N, Palacios JM, Mengod G (1992) Limbic seizures induce a differential regulation of the expression of nerve growth factor, brainderived neurotrophic factor and neurotrophin-3, in the rat hippocampus. Mol Brain Res 13:27-33.

Schwaller B, Buchwald P, Blümcke I, Celio MR, Hunziker W (1993) Characterization of a polyclonal antiserum against the purified human recombinant calcium-binding protein calretinin. Cell Calcium 14:639-648.

Smeyne RJ, Klein R, Schnapp A, Long LK, Bryant S, Lewin A, Lira SA Barbacid M (1994) Severe sensory and sympathetic neuropathies in mice carrying a disrupted TrK/NGF receptor gene. Nature $368: 246-248$.

Snider WD (1994) Functions of the neurotrophins during nervous system development: what the knockouts are teaching us. Cell 77:627-638.

Sofroniew MV, Cooper JD, Svendsen CN, Crossman P, Ip NY, Lindsay RM, Sagra F, Lindholm D (1993) Atrophy but not dcath of adult septal cholinergic neurons after ablation of target capacity to produce mRNAs for NGF, BDNF, and NT3. J Neurosci 13:5263-5276.

Sofroniew MV, Galletly NP, Isacson O, Svendsen CN (1990) Survival of adult basal forebrain cholinergic neurons after loss of target neurons. Science 247:338-342.

Soltesz I, Smetters DK, Mody I (1995) Tonic inhibition originates from synapses close to the soma. Neuron 14:1273-1283. 
Soriano E, Frotscher M (1993a) GABAergic innervation of the rat fascia dentata: a novel type of interneuron in the granule cell layer with extensive axonal arborization in the molecular layer. J Comp Neurol 334:385-396.

Soriano E, Frotscher M (1993b) Spiny nonpyramidal neurons in the CA3 region of the rat hippocampus are glutamate-like immunoreactive and receive convergent mossy fiber input. J Comp Neurol 333:435-448.

Soriano E, Nitsch R, Frotscher M (1990) Axo-axonic chandelier cells in the rat fascia dentata: Golgi-electron microscopy and immunocytochemical studies. J Comp Neurol 293:1-25.

Sovreviela T, Clary DO, Reichardt LF, Brandabur MM, Kordower JH, Mufson EJ (1994) TrkA-immunoreactive profiles in the central nervous system: colocalization with neurons containing $p 75$ nerve growth factor receptor, choline acetyltransferase and serotonin. J Comp Neurol 350:587-611.

Steininger TL, Wainer WH, Klein R, Barbacid M, Clive Palfrey H (1993) High-affinity nerve growth factor receptor (TrK) immunoreactivity is localized in cholinergic neurons of the basal forebrain and striatum in the adult rat brain. Brain Res $612: 330-335$.

Supèr H, Soriano E (1994) The organization of the embryonic and early postnatal murine hippocampus. II. Development of entorhinal, commissural, and septal connections studied with the lipophilic tracer DiI. J Comp Neurol 344:101-120.

Svendsen CN, Kew JNC, Staley, K, Sofroniew MV (1994) Death of developing septal cholinergic neurons following NGF withdrawal in vitro: protection by protein synthesis inhibition. J Neurosci 14:75-87.
Tóth K, Freund TF (1992) Calbindin $D^{28 k}$-containing neurons in the rat hippocampus: their immunoreactivity for $\mathrm{GABA}$ and projection to the medial septum. Neuroscience 49:793-805.

Tóth K, Borhegyi Z, Freund TF (1993) Postsynaptic targets of GABAergic hippocampal neurons in the medial septum-diagonal band of broca complex. J Neurosci 13:3712-3724.

Tóth K, Freund TF, Miles R (1995) Septal stimulation suppresses hippocampal synaptic inhibition in a combined slice preparation. Soc Neurosci Abstr 21:473.16.

Wetmore CJ, Cao Y, Petterson RF, Olson L (1991) Brain-derived neurotrophic factor: subcellular compartmentalization and interneuronal transfer as visualized with anti-peptide antibodies. Proc Natl Acad Sci USA 88:9843-9847.

Whittemore SR, Friedman PL, Larhammar D, Persson H, GonzálezCarvajal M, Holets VR (1988) Rat $\beta$-nerve growth factor sequence and site of synthesis in the adult hippocampus. J Neurosci Res 20:403-410

Zafra F, Castren E, Thoenen H, Lindholm D (1991) Interplay between glutamate and gamma-aminobutyric acid transmitter systems in the physiological regulation of brain-derived neurotrophic factor and nerve growth factor synthesis in hippocampal neurons. Proc Natl Acad Sci USA 88:10037-10041.

Zafra F, Hengerer B, Leibrock J, Thoenen H, Lindholm D (1990) Activity dependent regulation of BDNF and NGF mRNAs in the rat hippocampus is mediated by non-NMDA glutamate receptors. EMBO J 9:3545-3550. 